\title{
PROSPEK HUKUM ADAT LAUT DALAM PENGELOLAAN PERIKANAN DI KABUPATEN PIDIE JAYA PROVINSI ACEH
}

\author{
Sulaiman \\ Fakultas Hukum Universitas Syiah Kuala \\ Mahasiswa Program doktor Ilmu Hukum Fakultas Hukum Universitas diponegoro \\ E-mail: st_aceh@yahoo.co.id
}

\begin{abstract}
In a society still encountered the customary law of the sea became an essential component in the management of sustainable fisheries. Existence of customary law recognized law in Indonesia. This study examines how the working mechanism of customary law in relation to the prospects of fisheries management in pidie Jaya. The method used in this study was a composite of normative and empirical, with the intent to clarify the law governing customary law that had influence in fisheries management. Of research is that although governed by the statutory provisions, the implementation of customary law in the management of fisheries co-management mechanism should be various stakeholders. Indigenous communities can not carry out sea customary law independently. With the results of this study are expected to strengthen government oversight in order to support the sustainability of fisheries management, one of which is to carry out the customary law of the sea. Optimization of this function will be a positive impact not only on the customary law of the sea, but also for the protection of fisheries potential.
\end{abstract}

Key Words : customary law on the sea, fisheries management

\begin{abstract}
Abstrak
Dalam masyarakat masih ditemukan adanya hukum adat laut yang menjadi komponen penting dalam pengelolaan perikanan. Keberadaan hukum adat diakui di Indonesia. Penelitian ini ingin menjelaskan bagaimana mekanisme hukum adat laut dalam kaitannya dengan prospek bagi pengelolaan perikanan di Pidie Jaya. Metode yang digunakan dalam penelitian ini ini adalah dengan menggabungkan penelitian normatif dan penelitian empiris, dengan maksud menjelaskan hukum yang mengatur hukum adat yang berpengaruh bagi pengelolaan perikanan. Penelitian ini menemukan, meskipun diakui dalam ketentuan perundang-undangan, pelakanaan hukum adat dalam manajemen perikanan harus dilakukan melalu mekanisme pengelolaan bersama melibatkan berbagai pihak. Masyarakat adat tidak dapat melaksanakannya secara mandiri. Hasil penelitian ini diharapkan dapat memperkuat pengawasan pemerintah dalam mendukung pengelolaan perikanan secara berkelanjutan, salah satunya dengan melaksanakan hukum adat laut. Optimalisasi fungsi pemerintah akan membawa dampak positif tidak hanya bagi hukum adat laut, melainkan juga perlindungan potensi perikanan.
\end{abstract}

Kata Kunci: hukum adat laut, pengelolaan perikanan

\section{A. Pendahuluan}

Pada tingkat global sekalipun, terdapat konsensus menjadikan masyarakat lokal sebagai bagian tak terpisahkan dalam pelaksanaan pembangunan berkelanjutan. Konsensus tersebut dapat ditelusuri dari Deklarasi Stockholm 1972, Deklarasi Rio de Janeiro 1992, dan Deklarasi Johannesburg 2002 (Koesnadi Hardjasoemantri, 2005 : 35-39). Pada 1983, PBB membentuk World comission on Environment and Development (WCED) yang melahirkan World conservation Strategy (WCS). Simpulan mereka, konsep keberlanjutan berkaitan dengan menghargai dan memelihara komunitas kehidupan, meningkatkan kualitas hidup manusia, memberi kesempatan kepada masyarakat untuk memelihara lingkungannya sendiri (Koesnadi Hardjasoemantri, $2005: 12-13)$.

Keberadaan masyarakat lokal sangat penting sebagai modal sosial dalam rangka memanfaatkan sumberdaya (I Nyoman Nurjaya, 2008 : 31-32). Kapasitas budaya tersebut yang digunakan untuk menyeimbangkan antara pemanfaatkan dan penangkapan dan potensi 
yang diperkirakan (Sulaiman, 2012 : 3). Dengan demikian sumberdaya dapat dimanajemeni dengan kekayaan kearifan (Sulaiman, 2010 : 466).

Kearifan penting dimanfaatkan mengingat secara global kondisi perikanan dunia sebagian besar dieksploitasi berlebih (Sulaiman, 2010 : 464). Kondisi yang sama berlangsung di Indonesia. Seperti di Aceh, baik pesisir baratselatan maupun timur-utara sudah dalam kondisi di luar potensi lestari (T. Muttaqin, 2012 : 15). Kondisi demikian tidak terjadi dengan sendirinya. Kondisi tersebut terkait pengelolaan yang hanya diorientasikan untuk ekonomi (I Nyoman Nurjaya, $2008: 30$ )

Secara ideal sumberdaya perikanan diharapkan akan mencapai tujuan yang ideal, yakni menyelesaikan kemiskinan dan meningkatkan kesejahteraan. Salah satu pola yang dimungkinkan berdasarkan peraturan perundang-undangan adalah dengan pendayagunaan hukum adat laut.

Dalam Pasal 162 ayat (2) huruf e UndangUndang Nomor 11 Tahun 2006 tentang Pemerintahan Aceh, disebutkan dengan jelas bahwa salah satu kewenangan Pemerintah Aceh dan pemerintah kabupaten/kota adalah pemeliharaan hukum adat laut. Pengelolaan sumberdaya perikanan tersebut harus dilakukan dengan memperhatikan prinsip-prinsip pembangunan berkelanjutan dan pelestarian lingkungan hidup.

Di samping itu, Pasal 98 Undang-Undang Nomor 11 Tahun 2006, menyebutkan bahwa lembaga adat (salah satunya Panglima Laot) berfungsi dan berperan sebagai wahana partisipasi masyarakat dalam penyelenggaraan Pemerintahan. Dalam Pasal 7 Undang-Undang Nomor 44 Tahun 1999 Tentang Keistimewaan Aceh disebutkan bahwa Daerah dapat membentuk lembaga adat dan mengakui lembaga adat yang sudah ada sesuai dengan kedudukannya masing-masing di Provinsi, Kabupaten/Kota, Kecamatan, Kemukiman, dan Kelurahan/Desa atau Gampong.

Ada dua hal penting telah disebutkan tegas di atas, yakni pemosisian hukom adat laot dan pengelolaan perikanan dengan memperhatikan prinsip pembangunan berkelanjutan (Sulaiman, 2009 : 253). Gambaran di atas, dengan sendirinya menempatkan masyarakat hukum adat laut sebagai komunitas penting dalam kerangka pembangunan berkelanjutan wilayah perikanan dan lautan di Aceh. Masyarakat hukum adat laut adalah salah satu komunitas dan budaya berbasis masyarakat yang paling riil di Aceh (M. Adli dkk, $2005: 6)$.

Penelitian ini, diawali oleh dugaan bahwa masih ada kesenjangan antara hukum adat laot sebagai law in the book dengan hukom adat laot sebagai law in the action. Untuk menjawab dugaan ini, penelitian ini dilakukan dengan terlebih dahulu merumuskan permasalahan sebagai berikut: (1) pemosisian hukum adat laut dan Panglima Laot; (2) mekanisme bekerjanya hukum adat laut dalam hubungannya dengan prospek bagi pengelolaan perikanan di Kabupaten Pidie Jaya Provinsi Aceh; (3) Usaha yang dilakukan aparat penegak hukum dan hambatannya dalam melindungi hukum adat laut yang berkaitan dengan pengelolaan perikanan.

\section{B. Metode Penelitian}

Penelitian ini merupakan gabungan penelitian normatif (mengkaji perundang-undangan) dan empiris (melihat bekerjanya hukum). Spesifikasi penelitian, ingin melihat sejauhmana hukum yang mengatur tentang hukum adat laut mempunyai pengaruh dalam pengelolaan perikanan. Ada dua sumber data yang dipergunakan. Untuk menelusuri normatif, dipergunakan bahan hukum. Sementara untuk menjawab empiris, dilakukan serangkaian wawancara dengan nelayan dan pengurus lembaga hukom adat laot. Interveiw dilakukan tidak terpimpin (pertanyaan tidak disusun lebih dahulu). Sampel dipilih secara purposive sample (sampel bertujuan) dengan memilih anggota yang mencerminkan populasi (nelayan dan pengurus adat laot) yang sudah dikenal sebelumnya (Ronny Hadityo soemitro, 1983 : 10; Soerjono Soekanto, 2005 : 2008-220). Sampel yang dipilih adalah 10 orang nelayan dan 4 pimpinan lembaga adat laot. Untuk penelitian ini juga diwawancarai sejumlah informan dari akademisi dan aparat penegak hukum. Pengolahan data dilakukan dengan melakukan penafsiran (interpretatif), sedangkan laporan disusun dengan paparan dekriptif.

\section{Hasil Penelitian dan Pembahasan}

1. Pemosisian hukum adat laut dan Panglima Laot

Keberadaan hukum adat laut pada dasarnya merupakan kemajemukan normatif yang secara nyata hidup, dianut, dan masih 
dioperasikan masyarakat lokal (I Nyoman Nurjaya, 2008 : 40). Sederhananya nilai tradisional yang terdapat, tumbuh dan berkembang dalam sesuatu yang penting mendapat pertimbangan negara (Satjipto Rahardjo, 2006 : 112).

Sebagai hukum lokal ia berpotensi berubah. Bertahun-tahun tidak tegas, secara normatif kemudian ditegaskan dalam Pasal 18B ayat (2) Undang-Undang Dasar Republik Indonesia Tahun 1945, yang menyebutkan: "Negara mengakui dan menghormati kesatuan-kesatuan masyarakat hukum adat beserta hak-hak tradisionalnya sepanjang masih hidup dan sesuai dengan perkembangan masyarakat dan prinsip Negara Kesatuan Republik Indonesia yang diatur dalam undang-undang". Kalimat tersebut menunjukkan betapa negara merasa memiliki hukum adat (Satjipto Rahardjo, 2006 :111).

Konsep inilah yang kemudian membawa pengaruh terhadap konsepsi kesejahteraan, sebagaimana diamanahkan Pasal 33 ayat (3) UUD Negara Republik Indonesia 1945, bahwa bumi, air, dan kekayaan alam yang terkandung di dalamnya dikuasai oleh negara dan dipergunakan untuk sebesar-besar kemakmuran rakyat. Sumberdaya perikanan di Aceh merupakan kekayaan terpenting dalam mewujudkan kesejahteraan. Pemolaan pengelolaan dengan penekanan pada kenyataan kearifan lokal yang ada dalam masyarakat.

Berkaitan dengan penelitian ini, ada tiga penekanan penting yang secara eksplisit tersurat dalam Pasal 162 Undang-Undang Nomor 11 tahun 2006, yakni: pertama, pemeliharaan hukum adat laut sebagai kewenangan untuk mengelola sumberdaya alam yang hidup di wilayah laut Aceh. Kewenangan tersebut berbarengan dengan konservasi dan pengelolaan, pengaturan administrasi dan perizinan, tata ruang, penegakan hukum, dan pemeliharaan kedaulatan. Kedua, Pemerintah Aceh dan pemerintah kabupaten/kota berwenang menerbitkan izin penangkapan ikan dan pengusahaan sumber daya alam laut lainnya di laut sekitar Aceh sesuai dengan kewenangannya. Ketiga, pengelolaan sumber daya alam di wilayah laut dilakukan dengan memperhatikan prinsip-prinsip pembangunan berkelanjutan dan pelestarian lingkungan hidup. Pengaturan tersebut diperjelas kembali dalam Pasal 98 Undang-Undang Nomor 11 tahun 2006, menyebutkan bahwa lembaga adat (salah satunya Panglima Laot-lembaga yang melaksanakan hukum adat laut) berfungsi dan berperan sebagai wahana partisipasi masyarakat dalam penyelenggaraan Pemerintahan.

Keberadaan Panglima Laot diakui dengan Undang-Undang Nomor 44 tahun 1999 dan Undang-Undang Nomor 18 tahun 2001. Dalam Pasal 7 Undang-Undang Nomor 44 tahun 1999 disebutkan bahwa "Daerah dapat membentuk lembaga adat dan mengakui lembaga adat yang sudah ada sesuai dengan kedudukannya masing-masing di Provinsi, Kabupaten/Kota, Kecamatan, Kemukiman, dan Kelurahan/Desa atau Gampong".

Pasal 1 ayat (5) Perda Nomor 7 tahun 2000 disebutkan bahwa lembaga adat dibentuk suatu masyarakat hukum adat tertentu, mempunyai wilayah tertentu, harta kekayaan sendiri, berhak dan berwenang mengatur dan menyelesaikan hal-hal yang berkaitan dengan adat Aceh. Lembaga adat laot merupakan salah satu lembaga adat yang harus dipertahankan, dimanfaatkan, dipelihara, diberdayakan, dan dibakukan, disamping berbagai lembaga adat lain di Aceh. Pasal 1 ayat (14) menyebutkan Panglima Laot sebagai orang yang memimpin adat, adat-istiadat, dan kebiasaan-kebiasaan yang berlaku di bidang penangkapan ikan dan menyelesaikan sengketa.

Keputusan Gubernur Aceh Nomor: $523.11 / 012 / 2005$ (tertanggal 8 Maret 2005), dengan jelas menyebutkan bahwa mengukuhkan Panglima Laot dilakukan dalam rangka menyukseskan pembangunan subsektor perikanan, dengan tugas dan wewenang dalam kedudukannya sesuai adat membantu tugas pemerintah dalam pembangunan bidang subsektor perikanan dan masyarakat nelayan dalam arti luas.

Menurut Hakim Nya' Pha, tugas dan tanggung jawab Panglima Laot sendiri termasuk masalah pengaturan penangkapan ikan, serta mengatur tentang larangan pengrusakan lingkungan laut, di samping adanya pantang laot di hari-hari tertentu berimplikasi kepada berjalannya ekosistem 
(Hakim Nya'Pha, 2001 : 6). Dalam pandangan Sanusi M. Syaref, masalah kekuasaan Panglima Laot sudah berlangsung dalam masyarakat hukom adat laot, baik sebelum atau sesudah diatur dalam aturan perundang-undangan. Hal ini penting untuk mencatat bahwa masalah adat laot adalah sesuatu yang sudah berkehidupan dengan masyarakat nelayan di Aceh (Sanusi M Syaref, 2003 : 15).

Dengan gambaran tersebut, sesungguhnya tampak bahwa perkembangan lembaga tersebut sama sekali tidak berubah. Perubahan terjadi pada konsep pemosisian dari masing-masing rezim. Misalnya setelah UU otonomi khusus untuk Aceh lahir, keberadaan itu kemudian dikuatkan. Artinya dengan menekankan pada konsep pembangunan berkelanjutan, UU memberi ruang dan kewajiban bagi lembaga adat semisal Panglima Laot di Aceh. Di samping itu, penjelasan tersebut juga memperjelas posisi bahwa di samping berlandaskan hukum formal, proses pengelolaan sumberdaya alam dalam konsep pembangunan berkelanjutan, juga terdapat dalam aturan-aturan adat masyarakat hukum adat di Aceh.

Hukum adat laut di Aceh dapat ditafsirkan sebagai seperangkat aturan yang memberikan arahan dan pengaturan hubungan timbalbalik dalam proses pengelolaan wilayah laut beserta sumberdaya yang terkandung di dalamnya, lahir dan terwujud sebagai proses interaksi panjang umat manusia dengan lingkungannya di wilayah laut dan pesisir (Baso Syafiauddin, 2006 : 5).

Dalam pola kemasyarakatan, dalam konteks hukum adat laut, kepentingan individu dan kepentingan umum saling dihormati dan diakui yang pola pelaksanaannya berawal dari apa yang berlangsung lambat-laun disepakati sebagai sebuah pola kehidupan bersama dalam mengelola sumberdaya dalam kehidupan masyarakat (Sulaiman, 2012: 23). Pola kehidupan dalam mengelola sumberdaya secara berkelanjutan, sebenarnya sudah merupakan pola pengendalian yang berbasis masyarakat. Pola ini akan berjalan efektif karena dalam pelaksanaan pengawasan terhadap perilaku yang tidak sesuai, tidak memerlukan biaya dan tenaga khusus, melainkan oleh mereka sendiri (Sulaiman, 2012: 3-4).
Apa yang menjadi kenyataan dalam masyarakat hukum adat laut, menggambarkan apa yang disebut Soemitro sebagai potensi pengendalian sosial secara rasional masyarakat melalui pembentukan normanorma dan sanksi-sanksi (Ronny Hadityo Soemitro, 1985 : 46). Hukum adat laut dilaksanakan oleh Panglima Laot. Secara umum, Panglima Laot di Aceh memetakan peran dan fungsi Panglima Laot di Aceh dalam empat hal, yakni: (a) melestarikan hukum adat; (b) melestarikan adat-istiadat; (c) melestarikan kebiasaan-kebiasaan dalam masyarakat nelayan di NAD; (d) membantu pemerintah dalam pembangunan perikanan bila diminta (HT Bustaman, 2005 : 7).

Dalam melaksanakan fungsinya, Panglima Laot mempunyai tugas: (a) memelihara dan mengawasi ketentuanketentuan Hukom Adat dan Adat Laot; (b) mengkoordinir setiap usaha penangkapan ikan di laut; (c) menyelesaikan perselisihan/ sengketa yang terjadi di antara sesama anggota nelayan atau kelompoknya; (d) mengurus dan menyelenggarakan upacara Adat Laot; (e) menjaga/mengawasi agar pohon-pohon di tepi pantai jangan ditebang, karena ikan akan menjauh ke tengah laut; (f) merupakan badan penghubung antara nelayan dengan pemerintah dan panglima laot dengan panglima laot lainnya; (g) meningkatkan taraf hidup kehidupan nelayan pesisir (HT Bustaman, 2005 : 7).

Dalam pelaksanaan Rencana Strategis Panglima Laot se-Aceh yang dilaksanakan Panglima Laut Aceh pada 9-12 Desember 2006 di Banda Aceh, seluruh fungsi dan peran yang menjadi tanggung jawab Panglima Laot juga dibahas secara detail. Ada beberapa bahasan spesifikasi program, yang mencakup: (a) penguatan masyarakat nelayan, (b) penguatan hukum adat laot masyarakat nelayan, (c) pemberdayaan ekonomi masyarakat nelayan, (d) program beasiswa untuk pelajar dari kalangan nelayan miskin, dan (e) memelihara lingkungan dari kerusakan.

Jadi jelas, pengelolaan sumberdaya kelautan dan perikanan, secara khusus dibahas oleh Panglima Laot sebagai sesuatu yang sangat penting dalam konteks memelihara lingkungan dari kerusakan dan eksploitasi berlebihan demi kesinambungan dan keberlanjutan. 
Agar hukum adat laut berjalan sebagaimana yang diharapkan, dalam aturan juga disusun sebuah bab khusus yang mengatur tentang sanksi hukum bagi yang melanggar, di mana akan berhadapan dengan dua kemungkinan: (a) seluruh hasil tangkapan akan disita; (b) dilarang melaut selama 3-7 hari.

\section{Mekanisme bekerja dan prospek hukum adat laut}

Merujuk pada peraturan perundangundangan di Indonesia, memungkinkan berlakunya hukum adat laut dalam komunitas masyarakat adat laut di Aceh. Posisi adat laut dan lembaga adat laut tidak hanya dikenal dalam hukum adat laut semata. Posisi adat dan lembaga adat laot juga dikenal dalam peraturan perundang-undangan di Indonesia.

Apa yang diatur dalam dalam peraturan di atas, selaras dengan pengaturan tentang pengelolaan perikanan dalam UndangUndang Nomor 45 tahun 2009 tentang perubahan Undang-Undang Nomor 31 tahun 2004 Tentang Perikanan. Dalam Pasal 6 ayat (1) UU Perikanan menyebutkan bahwa pengelolaan perikanan dilakukan untuk tercapainya manfaat yang optimal dan berkelanjutan, serta menjamin kelestarian sumberdaya ikan.

Pengaturan yang sangat tegas disebutkan secara nyata dalam Pasal 6 ayat (2) UU Perikanan, yang menyebutkan bahwa pengelolaan perikanan untuk kepentingan penangkapan ikan dan pembudidayaan ikan harus mempertimbangkan hukum adat dan/ atau kearifan lokal, serta memperhatikan peran serta masyarakat.

Namun pun demikian, ketentuan perundang-undangan di Indonesia jelas mengatur posisi hukum adat laut, dalam pelaksanaannya tetap tidak bisa menumpukannya pada hukum adat laut semata. Ada tiga pihak penting yang saling terkait dalam pelaksanaan hukum adat laut dalam pengelolaan perikanan, yakni Pemerintah, lembaga adat, dan masyarakat dalam bentuk peran serta dan keberadaan hukum adat dan kearifan lokal.

Pengaturan hukum positif dan kenyataan aturan adat dan lembaganya, membutuhkan kerangka konkret berupa konsep dalam pengelolaan perikanan. Konsep ini bisa dilahirkan dari pertemuan Panglima Laot yang kemudian merumuskan manajemen pengelolaan perikanan di Aceh.

Masalah co-management dalam pengelolaan perikanan sangat membutuhkan pemikiran konkret, apalagi adat laut sangat strategis dalam rangka melakukan pengawasan dan melestarikan lingkungan. Tentu, co-management lebih luas dari itu. Konsep ini perlu kemudian dikonkretkan ke arah adanya bangunan manajemen bersama Pemerintah, Panglima Laot, nelayan dan masyarakat, sehingga tidak jalan sendirisendiri, juga dalam penyelesaian berbagai persoalan.

Manajemen ini sudah dikenal secara global. Di Aceh, kenyataan lokal, sudah seharusnya membuka mata semua unsur masyarakat bahwa potensi lokal tersebut sangat strategis dalam melahirkan manajemen pengelolaan bermanfaat global dan berbasis lokal dan masyarakat.

Berbagai pertemuan yang menyangkut dengan ko manajemen dilaksanakan oleh Panglima Laot. Menurut John Kurien, program tersebut dimaksudkan untuk menguatkan lembaga hukum adat laut sendiri dan dapat menjalankan tanggung jawab secara bersama-sama dengan lembaga lain. Dalam hal ini masalah pengelolaan perikanan tidak bisa berjalan sendiri-sendiri (John Kurien, $2007: 3)$.

Panglima Laot yang diharapkan memelihara, melaksanakan dan menyebarkan pengetahuan dan praktek dari hukum adat laut. Sebagai hukum adat, pelaksanaan dari adat itu sendiri dan efisiensi pelaksanaannya berdasarkan pengetahuan tentang hukum dan penghormatan sosial dengan kekuasaannya dalam masyarakat nelayan.

Menurut responden, perubahan dalam adat disebabkan oleh suatu variasi dari faktor-faktor tindakan bersama-sama. Namun secara umum dalam mengatur hubungan antara orang-orang yang menggunakan laut dan memanen sumberdayanya, evolusi dari adat berhubungan erat dengan ekologi yang dinamis dan kondisi sosial ekonomi yang berlaku dalam kondisi lokal. Adat juga dihubungkan erat dengan budaya dan etos agama pada kelompok. Hal ini yang belakangan faktanya melengkapinya dengan 
suatu jangkar yang membatasi tingkat dari penyimpangannya.

Dalam serangkaian wawancara yang dilakukan dengan Panglima Laot, diakui bahwa dalam beberapa pertemuan pun, masalah pembicaraan kembali terus dilakukan yang menyangkut dengan pengelolaan perikanan di Aceh. Menurut Panglima Laot, masalah pengelolaan bersama sebenarnya telah lama terjadi dalam kehidupan nelayan. Hal ini dapat kita lihat ketentuan-ketentuan yang diatur dalam ketentuan hukum adat laut. Umpamanya ketentuan tatacara penangkapan ikan di laut, tatacara bagi hasil, hari pantang laut, hari-hari khanduri laut, dan lain-lain. Hal ini semuanya bermaksud untuk ketentraman bagi kehidupan nelayan dalam mencari nafkah di laut secara bersama-sama.

Dalam kebersamaan dengan pemerintah, nelayan secara adat juga berperan serta dalam menjaga kelestarian sumberdaya yang secara langsung ikut menjaga dan melarang penangkapan ikan dengan cara memasang arus listrik, memakai racun, menggunakan bom, menggunakan pukat trawl, menyelamatkan jika mendapati ikanikan yang diberi tanda, dan sebagainya, menyelamatkan hutan-hutan bakau di tepi pantai dan sebagainya.

Terkait hal tersebut, para Panglima Laot menyebutkan bahwa dalam segala kegiatan, mereka senantiasa berkoordinasi dengan pemerintah, demikian juga sebaliknya. Hal demikianlah yang diharapkan terlaksana dalam pengelolaan perikanan di Kabupaten Pidie Jaya Provinsi Aceh.

\section{Tantangan dalam pengelolaan perikanan}

Menurut informan, terkurasnya ikan di perairan Aceh ini bukan karena nelayan Aceh. Kemampuan nelayan Aceh untuk mengambil sumberdaya sangat terbatas (Razali AR, 2009: 5-6). Yang menguras adalah asing yang tidak terkontrol. Pemerintah seperti tidak berdaya untuk mengawasinya. Atas dasar tersebut dibutuhkan komitmen berbagai stakeholders dalam menjaga sumberdaya secara lestari dan berkelanjutan.

Dinas Kelautan dan Perikanan mendapatkan beberapa temuan lapangan dalam bidang kelautan dan perikanan yang menyangkut dengan hukum adat laut, antara lain kondisi sebagian besar nelayan di Kabupaten Pidie Jaya dalam katagori masyarakat miskin. Pada saat yang bersamaan, terjadinya illegal fishing, unregulated dan unreported fishing di perairan pantai timur Aceh (termasuk Kabupaten Pidie Jaya) yang tidak terkendali. Pertarungan tersebut tidak seimbang karena armada tangkap nelayan di kawasan tersebut yang rata-rata masih konvensional (skala kecil dan tradisional). Dalam kondisi seperti itu, masih tidak didukung oleh sarana dan prasarana pendukung perikanan tangkap yang memadai.

Dalam hal ini, salah satu arah kebijakan penting dan strategis yang dibayangkan akan berdampak pada pemerataan kesejahteraan adalah pengelolaan, pengendalian dan pengawasan sumberdaya kelautan dan perikanan yang terintegrasi. Untuk masalah ini, hal yang mendesak adalah melaksanakan pengawasan dan pengendalian sumberdaya pesisir, kelautan dan perikanan melalui peningkatan koordinasi dengan lintas sektor.

Dalam hal pengawasan, terbatasnya kapal pengawasan menjadi salah satu hambatan utama dalam menjaga potensi sumberdaya perikanan. Di banding dengan luasnya laut, jumlah kapan di pesisir timur Aceh sangat tidak sebanding. Kondisi tersebut seyogianya membuka mata Pemerintah.

Di samping itu, kendala dan hambatan lain yang dihadapi adalah: (1) Sarana dan prasarana yang terbatas, bila dibandingkan luas perairan wilayah; (2) Tantangan alam (ombak, angin, dlI); (3) Pengetahuan peraturan masyarakat pengguna jasa laut/ pencari nafkah yang masih rendah; (4) Sosialisasi aturan perundang-undangan yang belum merata; (5) Hubungan komunikasi antara berbagai stakeholders masyarakat yang masih terbatas.

Secara makro, tantangan dan hambatan tersebut sekaligus akan berimbas pada realitas hukum adat laut. Berbagai kenyataan ketentuan adat menjadi tidak optimal terlaksana akibat berbagai kondisi yang disebutkan di atas. Kondisi ini sangat penting untuk ditangani secara menyeluruh, karena langkah tersebut akan memberikan kenyamanan bagi komunitas dalam menjalankan hukum adat laut. 
Ketidaknyamanan tersebut seharusnya bisa diantisipasi dengan salah satu contoh kasus yang di alami oleh Panglima Laot Meureudu. Selama ini bila ada masalah dengan khusus terkait dengan ketentuan hukum adat laut, kepolisian akan menyerahkan penyelesaian kepada masingmasing Panglima Laot. Seperti halnya terjadi konflik antara nelayan Ulim dan nelayan Panteraja yang diinisiasi penyelesaiannya oleh Panglima Laot Lhok Meureudu.

Demikian juga dalam melaksanakan tugasnya, pihak kepolisian tingkat sektor akan berkoordinasi dengan tokoh nelayan bila dijumpai masalah yang berkenaan dengan pelaksanaan ketentuan hukum adat laut. Namun demikian penyelesaian tersebut tidak boleh melebihi dari lingkup ketentuan hukum adat laut. Catatan ini menjadi penting agar dalam pelaksanaannya, Panglima Laot sendiri tidak melebihi batas kewenangan yang ada padanya.

\section{d. Simpulan}

Berdasarkan pembahasan tersebut, ada dua simpulan yang dapat dipetik, yakni: pertama, hukum adat laut diatur dengan UU Pemerintahan Aceh dan UU Perikanan. Dalam hal mekanisme, ada hukum adat laut yang sudah diputuskan dan ada yang dalam perjalanan waktu kemudian disepakati. Mekanisme bekerjanya hukum adat ini dalam operasionalisasinya dikuatkan dengan konsep manajemen bersama, antara Pemerintah, Panglima Laot, dan nelayan pada umumnya.
Seiring dengan hal tersebut, stakeholders juga terus melakukan kerjasama dan melakukan sinergisasi aturan hukum, khususnya aturan hukum adat laut dengan hukum nasional. Kedua, usaha yang dilakukan aparat penegak hukum menyangkut dengan kasus yang berkenaan dengan ketentuan hukum adat laut adalah menyerahkan kepada Panglima Laot.

\section{E. Saran}

Saran yang diajukan adalah pentingnya Pemerintah memperkuat pengawasan dengan menambah kapal pengawasan dan sarana prasarana lainnya dalam rangka mendukung pelaksanaan pengelolaan perikanan secara terpadu dan keberlanjutan, dimana salah satunya adalah dengan melaksanakan hukum adat laut. Pada akhirnya, optimal fungsi ini akan berimbas positif tidak hanya pada komunitas hukum adat laut semata, namun juga bagi perlindungan potensi sumberdaya perikanan di Kabupaten Pidie Jaya Provinsi Aceh.

\section{F. Persantunan}

Saya mengucapkan terima kasih kepada semua pihak yang telah membantu terlaksananya penelitian ini, antara lain: Pimpinan Fakultas Hukum Unsyiah, Panglima Laot Aceh, Pusat Studi Hukum Adat Laut Unsyiah, dan nara sumber yang tidak mungkin saya sebutkan satu persatu. Terima kasih juga disampaikan kepada Universitas Syiah Kuala Banda Aceh yang telah membiayai penelitian ini. 


\section{daftar Pustaka}

Anonimious. 2011. Pidie Jaya dalam Angka. Meureudu: Pemkab Pidie Jaya.

Baso Syafiauddin. 2006. "Optimalisasi Peran dan Fungsi Hukum Adat Laot/Panglima Laot dalam Pemanfaatan dan Pengelolaan Sumberdaya Kelautan dan Perikanan di Kabupaten Aceh Besar". Makalah Lokakarya Revitalisasi Pranata Sosial Panglima Laot dalam Pemanfaatan dan Pengelolaan Sumberdaya Kelautan di NAD. Banda Aceh: Dinas Perikanan.

Hakim Nya' Pha. 2001. "Panglima Laot: Peranannya dalam Lembaga Adat Laot”, Makalah Duek Pakat Panglima Laot se-Aceh. Banda Aceh: Panglima Laot.

HT. Bustamam. 2005. "Peranan Lembaga Hukom Adat Laot / Panglima Laot dalam Pengelolaan Sumberdaya Kelautan dan Perikanan di Provinsi NAD". Makalah Lokakarya Dinas Perikanan Provinsi Aceh. Banda Aceh: Dinas Perikanan.

I Nyoman Nurjaya. 2008. Pengelolaan Sumberdaya Alam dalam Perspektif Antropologi Hukum. Jakarta: Prestasi Pustaka Publisher.

John Kurien. 2007. "Manajemen Pengelolaan Pesisir". Makalah Workshop Rehabilitasi Sektor Kelautan Aceh. Banda Aceh: Dinas Kelautan.

Keebet von Benda-Beckmann. "Pluralisme Hukum, Sebuah Sketsa Genealogis dan Perdebatan Teoritis", dalam Rikardo Simarmata dkk. 2006. pluralisme Hukum, Sebuah pendekatan Interdisiplin. Jakarta: HuMa.

Koesnadi Hardjasoemantri.2005. Hukum Tata Lingkungan. Yogyakarta: UGM Press.

M. Adli dkk. 2005. Selama Kekayaan adalah Kearifan, Eksistensi Lembaga dan Hukom Adat Laot di Aceh. Jakarta: Yayasan Kehati.

Razali AR. 2009. Profil Perikanan Tangkap Aceh. Banda Aceh: Dinas Perikanan Aceh.

Ricardo Simarmata. 2006. Pengakuan terhadap Masyarakat Adat di Indonesia. Bangkok: UNDP.

Ronny Hadityo Soemitro. 1983. Metode penelitian Hukum. Jakarta: Ghalia Indonesia. 1985. Hukum dan Masyarakat. Bandung: Alumni.

Sanusi M. Syaref. 2003, Leuen Pukat dan Panglima Laot dalam Kehidupan Nelayan di Aceh. Jakarta: CSSP.

Satjipto Rahardjo. 2006. Negara Hukum yang Membahagiakan rakyatnya. Yogyakarta: Genta Press.

Soerjono Soekanto. 2005. pengantar penelitian Hukum. Jakarta: UI Press.

Sulaiman. 2009. Perubahan Peran Panglima Laot di Aceh. Jurnal Kanun No. 47 Tahun XIX, Agustus 2009. Banda Aceh: FH Unsyiah.

2010. Konsep Pengelolaan Sumberdaya Berbasis Kearifan Lokal Di Aceh Pada Masa Otonomi Daerah. Makalah Lokakarya 8 Tahun Otonomi Daerah. Malang: Universitas Brawijaya.

2012. Model pengelolaan Kebijakan perikanan. Banda Aceh: Bandar Publishing.

2012. panglima Laot: past, present, and Future. In Proceeding Training Small Scale Fisheries. Bangkok: ICSF.

T. Muttaqin. 2012. Tata Kelola Laut Aceh. Banda Aceh: Pusat Studi Hukum Adat Laut Unsyiah.

Peraturan Perundangan-undangan

Undang-Undang Dasar Republik Indonesia Tahun 1945.

Undang-Undang Nomor 44 tahun 1999 tentang Penyelenggaraan Keistimewaan Aceh.

Undang-Undang Nomor 11 tahun 2006 tentang Pemerintahan Aceh.

Undang-Undang Nomor 45 tahun 2009 tentang Perubahan Undang-Undang Nomor 31 tahun 2004 tentang Perikanan. 